\title{
Occupational Role Stress among Public Sector Banks Employees in Sri Lanka
}

\author{
PRABAHARAN.T ${ }^{1}$, PANCHANATHAM.N ${ }^{2}$ \\ ${ }^{1}$ Department of Management \\ Eastern University, Sri Lanka (EUSL) \\ SRI LANKA \\ ${ }^{2}$ Department of Business Administration \\ Annamalai University \\ INDIA
}

\begin{abstract}
:-
Banking is one of the very important sector in the Sri Lankan economy and the public sector banks play a big role in this context. However, after the privatization of financial sector in Sri Lanka the banking is become more competitive and the employees working in this sector struggle in achieving their targets given to them by their superiors. This situation making them very stressful not only in the work place but also in their personal life as well. Therefore, there is a need to identify that to what extent the organizational role related factor are the causes to occupational stress among the public sector bank employees. This is an exploratory study and carried out through field survey. Though this type of study is more useful to both state and private banks, this particular study covered only two important state banks namely Bank of Ceylon (BOC) and Peoples Bank (PB) functioning in the Eastern Province of Sri Lanka. The total of 120 employees and 60 from Peoples Bank and 60 from Bank of Ceylon were taken for the study based on Stratified Random Sampling method. The data were collected through a structured questionnaire followed by an open ended interview with bank employees. From the data collected from the respondents and the analysis made by the researcher the mean value of the total Occupational Role Stress (TORS) indicated as 89.9. Further, among the ten occupational stressors evaluated in this study, the inter-role distance (Mean value 9.8), role isolation (Mean value 9.5), and personal inadequacy (Mean value 9.6) of state bank employees in Sri Lanka have highly influenced to their occupational stress. Therefore, it has been revealed that there is a moderate - high level of occupational stress among the public sector bank employees in Sri Lanka.
\end{abstract}

Key Words: - Occupational Role Stress, Peoples Bank, Bank of Ceylon, Sri Lanka

\section{Introduction}

The banking sector in Sri Lanka has been one of the most potential avenue of employment specially to the youths. After the liberalization in Sri Lanka, a set of reforms were introduced in the Sri Lankan economy. Modern changes such as computerization, reduction of government shareholding in state banks, introduction of voluntary retirement scheme for excess staff, Etc. are some of these reforms. As the outcomes of these changes, the banks were multiplied in size and numbers and diversified their activities and getting into new products and services. Organizational membership is a dominant source of stress and the changing occupational roles especially in the banking sector are the main causes to reduced quality, productivity, health as well as the well being and morale of 
employees. Therefore, the study on occupational role stress among the employees in the public sector banks will help the top management of the BOC and peoples bank to plan their job design particularly in redesigning their job description and job specification and keep their staff members more motivated.

\section{Objectives of the study}

The primary objectives of this study were 1) To evaluate the Occupational Role Stress of the public sector banks employees with special reference to the State Bank Employees in the Eastern Province of Sri Lanka,

2) To identify the factors influencing the Occupational Stress among employees of the state banks, and

3) To recommend strategies to mitigate the stress in their jobs.

\section{Literature Review}

Stress has become a part of human life. It is also part of every employee's life. Stress has been defined in different ways over the years. The Oxfort Dictionary defined the stress as " a state of affair involving demand on the physical and mental health of an individual. Generally, it was felt as pressure from environment, then as strain within a person. The National Institute of Occupational Safety and health defined the Occupational Stress as " the harmful physical and emotional response that occurs when there is a poor match between job demands and the capabilities, resources, or needs of a worker". According to Sridhar Rao (2006), "Stress is perceived state of disturbed harmony produced by a stimuli condition or event called the stressor. The disturbance results from the person's inability to met the threats posed by the stressors or from his inadequacy to satisfy the demands imposed by it".

Management role of an organization is one of the aspects that affect work-related stress among workers (Alexandros- stamatios et.al, 2003). Role stress means anything about an organizational role that produces adverse consequences for the individual (Kahn and Quinn, 1970). Pareek (1983) pioneered work on the role stress by identifying as many as ten different types of organizational role stresses. Navedita Abrraham, Elena Philip described them in a following manner.

1. Inter-Role Distance (IRD) It is experienced when there is a conflict between organizational and nonorganizational roles.

2. Role Stagnation (RS) : This kind of stress is the result of the gap between the demand to outgrow a previous role and to occupy a new role effectively. It is the feeling of being stuck in the same role. Such a type of stress results in perception that there is no opportunity for one's career progression.

3. Role-Expectation Conflict: This type of stress is generated by different expectations by different significant persons about the same role; and the role occupant's ambivalence as to who to please.

4. Role Erosion (RE) : This kind of roe stress is the function of the role occupant's feeling that some functions which should properly belong to his/her roles are transferred to / performed by some other role. This can also happen when the functions are performed by the role occupant by the credit them goes to some-one else. Another manifestation is in the form of underutilization in the role.

5. Role Overload (RO): When the role occupant feels that there are too many expectations from the significant roles in his/ her role set, he or/she experiences role overload. There are two aspects of this stress: quantitative and qualitative. The former refers to having too much to 
do, while later refers to tings being too difficult and the accountability in the role.

6. Role Isolation (RI): This type of role stress refers to the psychological distance between the occupant's roles and other roles in the same set. It is also defined as role distance which is different from inter-role distance, in the sense that while IRD refers to the distance among various occupancy by the same individual. Role isolation (RI) is characterized by the feelings that others do not reach out easily, indicative of the absence of strong linkages of one's role with other roles, this can be geographic or systematic.

7. Personal Inadequacy (PI) : This type of stress arise when the role occupant feels that he/she does not have the necessary skills and training for effectively performing the functions expected from his/her role. This is bound to happen when the organizations do not impart periodic training to enable the employees to cope with the fast changes within and outside the organization.

8. Self-Role Distance: When the role a person occupies goes against his /her-self concept, then he/she feels self-role distance type of stress. This is essentially a conflict arising out of mismatch between the person and his/her job.

9. Role Ambiguity (RA) : It refers to the lack of clarity about the expectations of the role which may arise out of e lack of information or understanding. It may exist in relation to activities, responsibilities, personal styles, and norms.

10. Resource Inadequacy (RIn) : This type of stress is evident when the role occupant feels that he/she is provided with adequate resources for performing the functions expected from him /her role.

\section{Methodology}

This is an exploratory study and carried out through field survey. Though this type of study is more useful to both state and private banks, this particular study covered only two important state banks namely Bank of Ceylon (BOC) and Peoples Bank (PB) functioning in the Eastern Province of Sri Lanka. The total of 120 employees and 60 from Peoples Bank and 60 from Bank of Ceylon were taken for the study based on Stratified Random Sampling method. The data were collected through a structured questionnaire followed by an open ended interview with bank employees. Pareek (1983) pioneered work on the role stress identifying as many as ten different types of organizational role stresses. As such, the inter-role distance (IRD), role stagnation (RS), role expectation conflict (REC), role erosion (RE), role overload (RO), role isolation (RI), personal inadequacy (PI), self role distance (SRD), role ambiguity (RA), and resource inadequacy (RIn) were assessed in this study. Further, in order to find out the level of occupational stress among the employees of Peoples Bank and Bank of Ceylon, Duncan's mean test was conducted.

\section{Results and Discussion}

From the data collected from the respondents and the analysis made by the researcher the mean value of the total Occupational Role Stress (TORS) indicated as 89.9. Further, among the ten occupational stressors evaluated in this study, the inter-role distance (Mean value 9.8), role isolation (Mean value 9.5), and personal inadequacy (Mean value 9.6) of state bank employees in Sri Lanka have highly influenced to their occupational stress. Therefore, it has been revealed that there is a moderate - high level of occupational stress among the public sector bank employees in Sri Lanka. 
Table: 01 - Mean value of each organizational role stressors

\begin{tabular}{|l|l|l|}
\hline Dimensions of ORS & Mean & SD \\
\hline $\begin{array}{l}\text { Inter Role Distance } \\
\text { (IRD) }\end{array}$ & 9.8 & 32 \\
\hline $\begin{array}{l}\text { Role Stagnation } \\
\text { (RS) }\end{array}$ & 9.1 & 39 \\
\hline $\begin{array}{l}\text { Role Expectation Conflict } \\
\text { (REC) }\end{array}$ & 8.8 & 45 \\
\hline $\begin{array}{l}\text { Role Erosion } \\
\text { (RE) }\end{array}$ & 9.2 & 38 \\
\hline $\begin{array}{l}\text { Role Overload } \\
\text { (RO) }\end{array}$ & 9.1 & 41 \\
\hline $\begin{array}{l}\text { Role Isolation } \\
\text { (RI) }\end{array}$ & 9.5 & 30 \\
\hline $\begin{array}{l}\text { Personal Inadequacy } \\
\text { (PI) }\end{array}$ & 9.6 & 31 \\
\hline $\begin{array}{l}\text { Self Role Distance } \\
\text { (SRD) }\end{array}$ & 8.6 & 44 \\
\hline $\begin{array}{l}\text { Role Ambiguity } \\
\text { (RA) }\end{array}$ & 7.9 & 47 \\
\hline $\begin{array}{l}\text { Resource Inadequacy } \\
\text { (RIn) }\end{array}$ & 8.1 & 41 \\
\hline $\begin{array}{l}\text { Total Organizational } \\
\text { Role Stress(TORS) }\end{array}$ & $\mathbf{8 9 . 7}$ & $\mathbf{2 9}$ \\
\hline
\end{tabular}

Source: Surveyed Data

\section{Conclusion}

Therefore, it has been revealed that there is a moderate - high level of occupational stress among the public sector bank employees in Sri Lanka.

\section{Recommendation}

The study suggest that the both the peoples bank and Bank of Ceylon must focus on their brand image and try to reiterate the peoples that they are the most reliable financial institutions in Sri Lanka through the wide product and promotional mix. Further, they must introduce well advanced technologies which have been used in other well developed financial institutions in the world and trained their staff to provide better service to the public. The state banks in Sri Lanka can make their employees to be involved in the decision making process and adapt good HR policies and practices through which the employees could be motivated. Moreover, they must find the mechanism to reduce the routine work burden of their employees and try to create a good working environment in every branched of Peoples bank and Bank of Ceylon.

\section{Limitations of the study}

This study covers only two important state banks (Bank of Ceylon and Peoples Bank) and again it does not compare with any other state of private banks. Further, this study focus only the organizational role related stress factor in the public sector banks though there are many other factor including demographic variables influence on the occupational stress in an organization.

Therefore, it has been suggested that there is need for an another study which must overcome the limitations and constraints mentioned above.

\section{References}

Pareek.V.Bevand Management, School of Management studies, New Delhi, 1998

Robins StephenP. Organizational Behavior, Himalaya Publications, New Delhi, 2006

Admas. J.D (1980) on consuming Human resources University

The IASMS Journal of Business Spectrum

Indian Journal of Industrial Relations

BVIMSR's Journal of Management Research 